HAADER LEA 2015. Régi bor, új tömlő: sokadszor a Halotti Beszéd feze szaváról. Magyar Nyelvőr 139: $300-308$.

HEGEDÜS ATTILA

Pázmány Péter Katolikus Egyetem

\title{
Az új Etimológiai szótár néhány létező és hiányzó szócikkéről
}

A ZAICZ GÁBOR és társai szerkesztette, felettébb közhasznú és a képzőkre, ragokra s jelekre külön figyelmet fordító Etimológiai Szótár (2006) öt közszót (bogrács, könyv, sámán, tepsi, tundra) és öt népnevet (alán, besenyö, burját, mandzsu, tatár) vizsgáló szócikkéhez szólok hozzá, és két további, már kihalóban lévő közszó (boncsok, csája) s egy máig eleven népnév (kalmük) eredetét igyekszem pontosítani. ${ }^{1}$

Alán. Az alán népnév az új Etimológiai szótár szócikkében (ESz. 16), az ilyen nevü iráni népre vonatkozó „ókorban” időmeghatározás kiterjeszthető a középkorra. A szó, mint a szótár több címszava (asszony, híd, nemes, sajt stb.) bizonyítja, nemcsak történet-, de nyelvtudományi szakszó is.

Besenyő. A besenyő népnév az új Etimológiai szótár (ESz. 66) szerint ,„a török nyelvekben nem mutatható ki”, 1. azonban Kásgari Mahmúd 11. századi bäčänäk szavát és részletesen RÓNA-TAS és BERTA munkáját (WOT. 1: 121-122).

Bogrács. A bogrács szó (ESz. 74) eredetét illetően nincs kétség, hogy ez részben délszláv közvetítésű oszmán török elem, de a bakır 'réz' és az ă̆aç 'fa' összetételéböl (EWUng. 1: 116-117; Esz. 24b) nehezen származtatható. KAKUK ZSUZSA (1973: 56, 1977: 97-98) is a bakır származékának tartja. HASAN EREN török szófejtő szótára (1999: 34ab) szerint a bakraç esetében nem szóösszetételröl, hanem szóképzésről van szó: bakır+aç (a kicsinyítő képző - $A c ̧$ előtti szótag magánhangzója kiesett). Ugyanígy ítélt SEVORTJAN (1978: 46) és RÄSÄNEN (1969: 58b) is.

Talán érdekes megemlíteni, hogy JUDACHIN 1965 szerint a kirgiz bakïr 'réz' szó másodlagos jelentése 'metalličeskoe vedro = fémvödör' (102a), azaz itt anyagnévből lett edénynév; a kol bakïr, szó szerint 'kéz(i) üst', pedig 'nebolьšoj dorožnyj mednoj kotël (kotoryj privjazyvali k torokam) $=$ kis úti rézüst (melyet a nyereg teherszíjaihoz szoktak kötözni)'. Ezt azonban másutt (396b) így értelmezi: 'metalličeskij upolovnik = fém merökanál' (396b), és ennek jelentésbeli rokonául hozza a čoyun kašik, szó szerint 'öntöttvas kanál' összetételt, amely 'nebolıšaja skovorodka s ručkoj = kis serpenyő nyéllel' (364a). A čoyun 'öntöttvas' másodlagos jelentése ugyancsak 'fémedény'. (Fordított jelentésváltozást mutat a mai halha-mongol šājan / aa:dzpy/ 'porcelán', kalmük šāzn, šāzy 'porcelán; teáscsésze' $<$ kínai chá + zhōng 'teáscsésze'.)

Törökből valók a bogrács következő kalmük megfelelöi: bäkirs, baknrs, bäkrsnn, bakrsn 'Kasserolle, kleiner Kessel mit Griff und Deckel' (RAMSTEDT 1935: 38a), azaz 'nyeles és fedeles fazék' is. RAMSTEDT ehhez idézi a kazak baqïraš 'Kasserolle, Kessel (von Eisen

${ }^{1}$ A vizsgált szavakat betürendben közöljük. (A szerk.)

DOI: 10.18349/MagyarNyelv.2020.2.207 
od. Blech)' és az oszmán török baqraj 'Gefäss mit Stiel, Kaffeekocher' szavakat, melyeket végső soron perzsa eredetünek tekint, ami a fentiek értelmében nem lehet. MUNIN BEMBE szótárában a mai kalmük bakrsn szó 'kotël (ploskodonnyj)', azaz 'lapos fenekü üst' jelentésü.

Boncsok. Az oszmán törökből jött, ma már alig használt boncsok 'lófarkas lobogó' szavunk, érthető módon nem szerepel a 2006-os szótárban. Forrásául KAKUK (1973: 76) az oszmán török boncuk 'boule de verroterie; étandard turc à queue de cheval' szót adja meg, és említi, hogy a török boncuk 'üveggömb, üveggomb' és mencuk 'zászló' összekeveredhetett (KAKUK 1977: e szavakat nem tárgyalja). A szó végső forrása az EWUng. (1: 123-124) szerint perzsa közvetítéssel az arab manjūq.

Az arab szó, mely valóban a (visszakölcsönzött) török mencuk forrása, DozY szótárában (2: 617b) egy fajta zászlót ('espèce de drapeau') jelent, de ebből nemigen lehet a török bunčuq, sem a magyar boncsok. Az arab manjū q szó alakját tekintve ugyanolyan szerkezetü igenév, mint a Maḥmūd név, mely a hamada 'dicsér' igéből való, de nincs olyan n.j.q. gyökü arab ige, melyből képezni lehetne. Valójában ez a török mončuq/bončuq szó arabosított alakja; az $m$ szókezdő kipcsak török, valószínüleg egyiptomi mameluk eredetet sejtet. DOZY az arab szót egy Észak-Afrika és Spanyolország történetéről szóló munkához csatolt szójegyzékből idézi. A 'gyöngy; zászlórúd gömbölyü dísze; bojt; lófarkas lobogó' (pontosabban: 'rúdon függő, lószőrből, pl. hosszú sörényből való, bojtszerü hadi jelvény') stb. jelentésü török mončuq/bončuq stb. népes családját és számos török, mongol és más nyelvbeli elterjedését - a magyar szó kivételével - DOERFER részletesen tárgyalja (TMEN. 4: 24-26, 1740. szócikk). Török és mongol adatai tovább bővíthetők; közülük itt csak az ujgur írású mongol mončoyi- 'gömbölyödik, gömbölyü(vé válik)' hangfestő igét idézem, melynek származéka - vagy visszaképzés esetén forrása - a mončo $\gamma$ '(gömbölyü) bojt', és rokona, elhasonult alakja, a molčo $\gamma$ 'bojt a ló nyakán; állat bőre alól dudurodó zsírgöb' névszó). L. még: LEVITSKAJA-BLAGOVA-DYBO-NASYLOV 2003: 72-73, ahol egy helyett két különböző török szó, mōnjuk és monjak, szerepel. A szerzők idézik DoERFERt, de nem térnek ki az arab szóra, és a 'gyöngy' és 'zászló' jelentés mögé nem névátvitelt, hanem (hitem szerint feleslegesen) külön-külön eredetet tételeznek fel.

Burját. A burját mongol népnév (ESz. 91) burjátul burjād, cirill betüvel буряад, bár a szovjet időkben évtizedekig a véghangsúlyos orosz буряm volt a hivatalos írott alak. 17-18. századi orosz okmányokban a burjátok neve брацкие ясашые людишки azaz 'adózó brácki (= burját) emberkék'. A 13. századi Mongolok Titkos Történetében buriyat alakot találunk. Több más mongol nép- vagy nemzetségnévhez hasonlóan (pl. bulayad 'cobolyok', dörböt 'négyek', ikires (burját ehired) 'ikrek', qaүučid 'a régiek', kesigten 'a nagykáni testőrgárda tagjai', torүud 'torgút' < középmongol turqa'ut 'nappali testőrök') ez is többes szám alakú. Tövének jelentése, mint a nyugati mongolok és köztük a kalmükök ojrát (középmongol oyirat) népnevéé is, ismeretlen. Barguzini tunguz (evenki) szomszédaik boriey és borieyingkur néven ismerték őket.

Csája. A csája szó az ESz.-ban nem szerepel, a magyarban orosz eredetü jövevényszó (EWUng. 1: 184). Az orosz čaj 'tea' - BÁLINT GÁBOR is fizette az orosz imsikek, azaz postakocsisok „,csájára valóját” (SZENTKATOLNAI BÁLINTH 1874) - és kínai forrása között török és mongol nyelvek közvetítettek; ezekből és a perzsából van az orosz szó végén 
a j (1. TMEN. 3: 39-43, 1057. szócikk; EREN 1999: 81-82). 1728 után a kínai tea mint „orosz tea” az északi „teaúton”, az orosz és a mandzsu birodalom mongol nevü határvárosának, Kjahtának (Kiyaytu) piacán cserélödött más kínai és mongol árukkal együtt nyugati javakra.

Kalmük. Hiányzik a szótárból a kalmük mongol népnév. Ez kalmükül ma xaljmpg, cirill betüvel хальмг (SzENTKATOLNAI BÁLINTH GÁBORnál khálymik khalymik [1875: 10], mongol írásban qalima , baskirul, kirgizül kalmak, németül Kalmück, oroszul (véghangsúlyos) кальмг, amerikai angolul ma Kalmyk), a mongol qali- 'túlcsordul, kiárad' ige származéka. Az 1870 táján kalmük földön járt BÁLINTH szerint a kalmükök szívesebben használták az ojrát (kalmükül örd) nevet. A kalmük név a 20. században lett igazán sajátjuk - különösen azután, hogy 1944-ben Sztálin számüzte őket, s a kalmük szót még a szovjet enciklopédia 2. kiadásából is törölték -, majd akkor, mikor Hruscsov idején visszatérhettek Volga melléki hazájukba, s a kalmük „név megint szép lett”. Néhány régi török szavunknak (kender, köris, som, sőreg) csak ebből a nyelvből van mongol megfelelöje.

Könyv. Az Etimológiai szótár könyv szócikkében (ESz. 445) felsorolt „,vándorszók” közül törlendő a koreai kwen (kwŏn) 'könyv' és az ujgur küin 'könyvtekercs' szó. Mindkettő egy közép-kínai szóból származik, melynek mai észak-kínai alakja juan (magyar népszerü átírásban csüan, az akadémiai átírásban küan, ez utóbbi egy korábbi hangalakot jelöl). Ereszkedő hanglejtéssel ennek a hangsornak (és hanglejtéssel együtt immár morfémának) 'papírtekercs; könyv; írásmü, okmány', ereszkedö-emelkedő hanglejtéssel 'összeteker' a jelentése. Ha szókezdőjét hehezetesre és hanglejtését emelkedőre váltjuk, akkor ez a 'fodor; bodor; bodorít' jelentésü quan (magyar akadémiai átírásban k'üan). Eredeti jelentése 'tekercs; teker', melyet képi eredetủ írásjegye még mai, kései alakjában is sejtet. A szó előfordul már az ókori Dalok Könyvében (Shijing) és Konfuciusznál (1. KARLGREN 1957. 226a). A Han kori (i. sz. 100 körüli) Shuowen szótár szerint ’teker; tekercs' és 'csavart, tekeredö, görbe'. Megvan nemcsak a koreai, de a japán és a vietnámi nyelv kínai elemei közt is (jap. ken és kan, viet. quyê'n). A mongol kori ómandarin kínai rímszótárban, a Kubilaj császár bevezette négyszögírásos Menggu ziyunben mint $k$ ’ön és gön (átbetüzve k'äon és gäon ahol äo $=\ddot{o}$; CoBLIN [2007: 516-517] szerint yo) szerepel. A mandzsuban giowan (= giuwan) alakban élt, és a hagyományos formájú, kettős lapú kínai könyv fejezeteit, nem magát a könyvet jelentette. Az ujgur írásos régi törökben e kínai szó hangsorát négy betü, kwyn (kāph, waw, yodh, nūn) jelöli, melynek hagyományos olvasata kuin - a Drevnetjurkskij slovar' (DtS.) szerint kuyn -, de mert az y betü $y$, $i$, $i$ és $e$ hangot, a $w$ betü meg akármely ajakkerekítéses magánhangzót egyaránt jelölhet, a szó lehet kuen, küen, sőt, a mongolkori észak-kínai szerint kön is. A magyar könyv-nek azonban se nem rokona, se nem őse, és mint a fentiekből remélhetően világos, a kínaiban nem vándorszó. RÓNA-TAS és BERTA West Old Turkic (WOT.) alapos könyv szócikkében (1: 590-593) idézi és joggal elveti MUNKÁCSI hasonlítási ötletét is, amely szerint idetartozna a mandzsu kiyan 'egy konc ívpapír' vagy 'köteg', de a HAUER (1952) mandzsu szótára alapján hozzátett magyarázat hibás. HAUER nem állítja, hogy ez a mandzsu papíripari szó azonos volna akármelyik kínai szóval, melyek írásjegyeit felsorolja, csak azt, hogy a kiyan mandzsu betüsor ezen azonos hangsorú kínai szavak mandzsu kori észak-kínai hangzásának szabályos átírása. HAUER a mandzsu (részben papíripari) szó kínai megfelelőjét is megadja: ez dāo, közönséges jelentése 'kés'. A mandzsu kiyan lehet kínai eredetü, de nem abból 
való, melyet a WOT. 591. oldala mutat. Különben a mandzsunak van kiyala- szava is, mely a könyvösszefüzés, a kínai módú könyvkötés igéje.

Mandzsu. A mandzsu nép-, nyelv- és birodalomnév jelentése - az ESz. 512 és az EWUng. 2: 933b ellenére - ismeretlen. A mandzsu birodalom kínai Qìng (magyar akadémiai átírásban $C$ 'ing) nevének közszói jelentése 'világos, áttetszö, tiszta', de ez nem érvényes a mandzsu szóra, ahogy a mongol névnek sincs köze a Kínát is uralt mongol birodalom és uralkodóház kínai Yuan (Jüan) nevének 'első; fö; hatalmas' stb. jelentéseihez. A szó mandzsuul manju, előbb - mint a mongol is -, csak nemzetség- vagy törzsnév; kínaiul mănzhŏu; ez utóbbi szótagos, hanghelyettesítő átírás. A szóbelseji zárréshang zöngétlensége az angol Manchu, olasz mancese, régebbi francia mantchou (ma mandchou) stb. alakban a kínai félzöngés vagy zöngétlen, de nem hehezetes szupradentális zárréshang $z h$ korábbi angol $c h$, régebbi francia tch átírásából való. (A budavári Hadtörténeti Múzeum előtt álló két 17 . század végi mandzsu ágyú feliratán, melyen a tervező tudós belga jezsuita Ferdinand Verbiest, aki egy latinul írt mandzsu nyelvtan szerzője is, a kínai nevén szerepel, a birodalom neve mandzsuul Dayičing gurun 'a Nagy Csing ország'.)

Sámán. A magyar sámán szó orosz elődje (šamán) bizonyosan nyugati vagy délnyugati evenki nyelvjárásból való (šamān), mert másutt a szó alakja samān vagy hamān. (Keleti evenkiből való a mongol dahúr samā̌̌ke 'sámánviselet'.) A s $\bar{a}$-/šā-/hā- 'tud' igéből nemigen eredeztethető, ez utóbbi származéka a sāman/sāmen/sāme 'jel, útjelző' (vö. CINCIUS szerk. 1975-1977. 2: 59). Az ujgur írású mongol ja aүarin '(magas rangú) sámán’ és középmongol

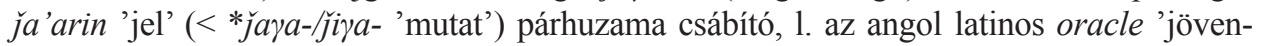
dőmondó; jóslat; jóshely' szavát és orákulum szavunkat. A sāman 'jel' és a samān'sámán' csak úgy volna egyeztethető, ha feltennénk, hogy e mai két szó szóhasadás eredménye, melyet a rövid és hosszú magánhangzó felcserélése szentesített, de ez már „emeletes” és emiatt ingatag feltevés volna. A tunguz nyelvek 'sámán' jelentésű szavát többen konokul a szanszkrit śramaṇa 'hívő; buddhista szerzetes; kolduló barát' szóval rokonították, és ezt tokhár nyelvi közvetítés feltevésével támogatták, amint ezt VASMERnél is olvassuk (1973. 4: 401). Ez azonban nem bizonyítható, annak ellenére, hogy előfordul, ha nem is azonos, de

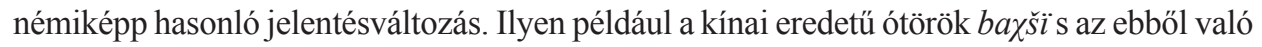
klasszikus mongol baүši '(tanító)mester' szó esetében, melynek kazak és kirgiz megfelelője 'javasember, sámán' jelentésü. (A mai észak-kínai bósh̄̄ és kínai elemekkel telített kelet- és délkelet-ázsiai nyelvekbeli megfelelői világi tudós fokozatot, bölcsészdoktort jelölnek). A célba vett ind szó és társa, a šramaṇera 'tanítvány', a középinden és a kelet-turkesztáni indoeurópai nyelveken át a kínai (shami) közvetítéssel jutott a buddhista ótörökbe, majd onnan a mongolba šabi alakban, ahol a jelentése általában 'tanítvány', ebből pedig a 17. századtól a 20. század elejéig kb. 'kolostorjobbágy' (többes alakban šabinar). A mongol baүši továbbjutott a mandzsuba (baqsi 'tudós, tanult ember'), de nem a szibériai tunguzba.

Tatár. A tatár népnév az Etimológiai szótár szerint (ESz. 831) a mongol tatari 'dadogó' szóra vezethető vissza, ami nem lehet, mert e népnév a mongolban és középmongolban tatar alakú, és tudtommal mongolul nincs tatari 'dadogó' szó. A dadogás igéje egere-, mai mongolul eere-, ebből eerü̈̈ 'dadogó'. Egyedül RAMSTEDT kalmük szótára említ egy kelet-turkesztáni ojrát (Csugucsak környéki őlöt) tatr szót, melynek jelentése 'mit fremder Aussprache', azaz 
'idegen(es) kiejtésü', tatr kü̈n 'einer, der die Sprache nicht gut beherrscht, ein Stotterer', azaz 'aki nem jól tudja a nyelvet; dadogó'. A RAMSTEDT kikövetkeztette régi alak tatari, nyilván okkal nem tatar (1935: 384a). RAMSTEDT ugyane címszóban megad két rokon jelentésü szót: tat $^{p} t s^{p} t \bar{\varepsilon}$ és $k e l k \bar{\varepsilon}$, az elöbbi töve szerepel külön címszóként mint tat ${ }^{p} t s p$ 'das Ziehen; Hineignung, Lust', azaz 'húzás, vonzás; vonzalom, kedv (vmihez)' és az oros $\operatorname{tat}^{p} t{ }^{n}{ }^{p} t \bar{\varepsilon}$ 'mit russischer Aussprache', azaz 'oroszos kiejtésü' összetételben (i. h.). Három kelkē szó közül az egyik 'stotternd, nicht deutlich redend; stumm (= der keine Antwort findet)', azaz 'dadogva, nem világosan ejtve a szót; némán (mint aki nem tud válaszolni)' (223), mai kalmükül kelkä 'dadogó'. - 8. század eleji türk rovásfeliratok említik a „harminc tatár” és a „,kilenc tatár” népet. A Mongolok Titkos Történetében a tatar egy népes mongol nép neve. A mai mongóliai mongol tataar és a kalmük tatar (= tatār) szavának hosszú magánhangzója az oroszból való, ahol a szó véghangsúlyos: tatár, régebben totár is, mellyel az orosz birodalom sokféle „pogány” népét illették, pl. a kamcsadálokat is. (A török nyelvü tatárok régebbi kalmük neve maygnD

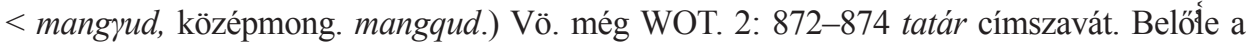
'dadogó' törlendő, a vele együtt az idézett tatari 'adó' szó is, mely a tata- 'húz, von' ige származéka, csakúgy mint a tataburi 'adó', s ezeknek a tatár népnévhez nincs bizonyítható köze.

Tepsi. A tepsi szócikkhez (ESz. 839) hozzáteendő, hogy ez a szavunk végső soron kínai eredetü, az idézett perzsa tabši a középmongol tebši átvétele (1. TMEN. 1: 249-251. 123. szócikk), ez utóbbi régi törökből (tevsi stb.) való (vö. CLAUSON, ED. 445. sköv.). A kínai összetett szó ma északon diézi, középkínaiban dep tsi alakú, jelentése 'tál; tányérka' stb.; a második szótag 'gyermek' jelentése révén vált előbb kicsinyítő, majd a tárgyi-dologi jelentést biztosító elemmé (azért nem mondom, hogy fönevesítő, mert a kínaiban nem igazán érvényesek a mi latin és német mintájú szófaji fogalmaink). A régi töröknek nem volt szókezdő $d$-je, a jövevényszók a szókezdő $d$-t $t$-re, a kínai összetétel második tagjának zárréshangját réshangra váltotta, és a középmongolba ez ment tovább, miközben a mongol a számára idegen $v$-t $b$-re, majd az $i$ elötti $s(s z)$-et $s ̌(s)$-re cserélte. Az észak-kínai diézi az újabb mongolba közvetlenül is bekerült, ahol ma a régibb tebši (ma tewš) 'tál' és az újabb diidz [di:cz] 'tálka' egymás mellett él. Sok áttételen keresztül is kínai gyökerü voltában a magyar tepsi a gyöngy, a tea és a csája társa.

Tundra. A tundra szót a szótár - helyesen - elsősorban az oroszból származtatja, az orosz túndra szót pedig a finn tunturi szóval és lapp megfelelöjével (duoddâr 'magas, kopár hegy') egyezteti. Az orosz szó forrásául az evenki (tunguz) dunne 1. 'föld, világ; ország; helység', 2. 'sír(hely)', dunde és a legnyugatibb (Sym) nyelvjárásbeli dundre 'föld, talaj; sír' is szóba került. Lásd e szót VASILEVIČnél (126), ugyanott több rokon nyelvi megfelelővel, köztük az even (lamut) dunre 'hegyvidék; tajga' szavával (1. még CINCIUS szerk. 1975-1977. 1: 224a). A szó az evenki hősmesékben leginkább 'föld, világ' jelentésű, Kodakcsen történetében például dulin dunne dulkaakinduun 'a középső világ kellős közepén'. Igaz, az evenkinek vannak külön 'tundra' jelentésű szavai, pl. det, de az is igaz, hogy az evenki világ jórészt tundra. Az orosz szó MARTTI RÄSÄNENtől felvetett evenki eredetét VASMER (1973. 4: 120-121) hangtani nehézségek miatt elutasítja. ČERNYCH orosz történeti-etimológiai szótára (1994. 2: 271) megkérdőjelezi a szónak mind a finn, mind a tunguz etimológiáját, feltételesen lehetőnek tartja belső, orosz tőből való származtatását, de végül a bizonytalan eredetü szavak közé sorolja. 


\section{Hivatkozott irodalom}

ČERNYCH, PAVEL J. 1994. Istoriko-êtimologičeskij slovar' russkogo jazyka 1-2. Russkij jazyk, Moskva.

CINCIUS, VERA IVANOVNA szerk. 1975-1977. Sravnitel'nyj slovar'tunguso-man'čurskich jazykov 1-2. Hajka, Leningrad.

Clauson, ED.= Clauson, Sir Gerard, An Etymological Dictionary of Pre-Thirteenth-Century Turkish. The Clarendon Press, Oxford, 1972.

Coblin, W. South 2007. A Handbook of 'Phags-pa Chinese. University of Hawai'i Press, Honolulu.

Dozy, R. 1967. Supplément aux dictionnaires arabes 2. Troisième édition. Brill - Maisonneuve et Larose, Leide-Paris.

DtS. = NADELJAEV, V. M., Drevnetjurkskij slovar'. Akademija SSSR, Leningrad, 1969.

EREN, HASAN 1999. Türk dilinin etimolojik sözlüğü. Bizim Büro Basım Evi, Ankara.

ESz. = Etimológiai szótár. Főszerk. ZAICZ GÁBOR. Tinta Könyvkiadó, Budapest, 2006.

EWUng. = Etymologisches Wörterbuch des Ungarischen 1-2. Hrsg. BENKÖ, LORÁND. Akadémiai Kiadó, Budapest, 1993-1995.

HAUER, ERICH 1952. Handwörterbuch der Mandschusprache. Otto Harrasowitz, Wiesbaden.

JUDACHIN, K. K. 1965. Kïrgïzča-orusča sözdik. Kirgizsko-russkij slovarb. Sovetskaja Ênciklopedija, Moskva.

KAKUK, SUZANNE 1973. Recherches sur l'histoire de la langue osmanlie des XVI ${ }^{e}$ et XVII ${ }^{e}$ siècles. Les éléments osmanlies de la langue hongroise. Akadémiai Kiadó, Budapest.

KAKUK, ZSUZSA 1977. Cultural words from the Turkish occupation of Hungary. ELTE Turkish Department, Budapest.

KARlgren, Bernhard 1957. Grammata Serica Recensa. Museum of Far Eastern Antiquities, Stockholm.

LeVitsKaja, L.S. - Blagova, G. F. - DyBO, A. V. - NASYLov, D. M. 2003. Ettimologičeskij slovarb tjurkskich jazykov. Obščetjurkskie i mežtjurkskie osnovy na bukvy L, M, N, P, S. „Vostočnaja literatura" RAN, Moskva.

Munin Bembe (= B. D. Muniev) 1977. Xalbmg-oros tolb. Kalmycko-russkij slovarb. Ors keln. Russkij jazyk, Moskva.

RAMSTEDT, G. J. 1935. Kalmückisches Wörterbuch. Suomalais-Ugrilainen Seura, Helsinki.

RÄSÄNEN M. 1969. Versuch eines etymoligischen Wörterbuchs der Türksprachen. SuomalaisUgrilainen Seura, Helsinki.

SEVORTJAN, ÊRVAND V.1978. Etimologičeskij slovarb tjurkskich jazykov, 2. Nauka, Moskva.

SzENTKATOLNAI BÁlinTH GÁBOR 1874. Bálinth Gábor jelentése Oroszország- és Ázsiában tett utazásáról és nyelvészeti tanulmányairól. Eggenberger-féle Akadémiai Könyvkereskedés, Budapest.

TMEN. = DOERFER, GERHARD, Türkische und mongolische Elemente im Neupersischen 1-4. Franz Steiner Verlag, Wiesbaden, 1963-1967.

VASILEVIČ, GLAFIRA M. 1958. Êvenkijsko-russkij slovar'. Gosudarstvennoe izdatelıstvo inostrannych i nacionalsnych slovarej, Moskva.

VASMER, MAX 1973. Êtimologičeskij slovar' russkogo jazyka 1-4. Progress, Moskva, 1964-1973. WOT. = RÓNA-TAS, ANDRÁS - BERTA, ÁRPÁD, West Old Turkic. Turkic Loanwords in Hungarian 1-2. Harrassowitz, Wiesbaden, 2011. 